\title{
Nasser the Radio Star and Sound Icon in Arab Collective Memory
}

\author{
Afif Arabi \\ Lebanese International University \\ sahar.sharara@liu.edu.lb
}

\author{
Sahar Sharara \\ Lebanese International University \\ afif.arabi@liu.edu.lb
}

\begin{abstract}
On November 14, 1954, Gamal Abdel Nasser became the president of the Republic of Egypt and the iconic leader of the Arab world. He was the first Arab leader to successfully capture the hearts and minds of Arabs across the colonial divide in the Middle East and North Africa. Much of this success is generally due to his nationalist ideology and mainly due to his charismatic character and his passionate voice. He became the anti-colonial voice and 'radio star' president of all Arabs. His hours long speeches broadcasted live over the radio across the Arab world. Hundreds of millions of Arabs attentively tuned to his speeches at homes, in cafés, in cars listening to him individually and in groups. His radio addresses became a cultural activity ingrained in the memory of Arab adults and children till present time. This paper examines the history of the sound culture created by Nasserism and its omnipresence in the collective memory of Arab minds. This sound culture is comprised of Nasser's unique radio performance - his voice and delivery style, and of the Nasserist political song genre in Egypt and the Arab World.
\end{abstract}

Sound culture. Media Art History. Radio performance. Nasserism. Speech delivery. Political Songs. Pan-Arabism. Post-Colonialism.

\section{INTRODUCTION}

In 1952, a group of Egyptian military officers led by Mohammed Naguib and Gamal Abdel Nasser orchestrated a successful coup d'état in Egypt and overthrew the British backed monarch, king Farouk. This event became to be known as the July $23^{\text {rd }}$, 1952 revolution by the Free Officers Movement. The immediate outcome of this revolution was the end of the British occupation of Egypt and its ruling arm - the Muhammad Ali dynasty, the establishment of the Egyptian republic, the beginning of the Nasserism era, the Arab socialism and the Arab Nationalism. The arrival of Nasser into the Egyptian and Arab scene was at a critical crossroad for the Arab World which paved the ground for his anointment as a legendary leader for all Arabs. Many of the Arab countries were still under colonial occupation while only a handful had their recent independence. In addition, Arabs were still under the influence of defeat as a result of the loss of Palestine to the Jews in the 1948 war. In general, Arabs including Egyptians were going through a severe socio-political strife to regain their independence and unity lost by long Ottoman and colonial occupation.
This turmoil environment shrouded by sense of defeat made Arabs in the Middle East and North Africa thirsty for a charismatic leader to navigate

them through these dark times. In his coup against the Egyptian royal dynasty, his vocal adversary to Imperialist powers, his call for unity and his opposition to Israel proved Nasser to be the leader they were awaiting. Nasser was successful in developing his own socialist ideology, known as Nasserism, built on the six principles of the revolution. As outlined by Hanna and Gardner (1969, p. 103), these principles were:

(i) the eradication of all aspects of imperialism,

(ii) the extinction of feudalism,

(iii) the eradication of monopolies, and the control of capitalistic influence over the system of government,

(iv) the establishment of strong national army,

(v) and, the establishment of a sound democratic society.

These principles spoke to the vast majority of Arabs who dreamed to live an honorable life under social justice. Nasser's popularity in Egypt and the Arab world soared in the aftermath of his nationalization 
of the Suez Canal and his victory against England in the Suez Crisis. Nasser "became an icon at home and across the Arab and non-aligned world, his reputation hugely enhanced by the success of his anti-imperial 'impudence"' (Searle, 2001, p. 66). By 1957, pan-Arabism had become the dominant ideology in the Arab world, and the average Arab citizen considered Nasser his undisputed leader (Dawisha, 2009, p. 184). Pan Arabism an idea that dominated the political consciousness of modern Arabs built on the myth of Ummah Arabiyya wahida dhat Risala Khalida [One Arab nation with an immortal vision] (Ajami, 1979, p. 355). Pan Arabism advocated the actual existence of a one Arab nation bound by the common ties of language, territory, religion and history. Arab nationalist terms such "Arab homeland" and "Arab nation" frequently began appearing in his speeches in 1954-55, whereas prior he would refer to the Arab "peoples" or the "Arab region" (Jankowski, 2001, p. 32). In the words of Mohamed Hassanein Haikal, Egypt became the embodiment of this idea and this historical movement (Ajami, 1979, p. 356). Despite the heavy defeat in the 1967 war against Israel, Nasser continued to enjoy massive support of the Arab people. Nasser "appeared in the eyes of most Arabs and much of the outside world, as the symbol of the movement of Arab peoples towards greater unity and genuine independence" (Hourani, 369). After his death, Nasser became a martyr to the cause of Arab brotherhood (Kerr, 1971, p. 155). According to Gordon (2006, p. 4) "Nasser and his era remain pivotal to Egyptian, Arab, Middle Eastern and post-colonial world history". In Arab collective memory, Nasser continues to be remembered as "the ultimate champion of Arab nationalism, heroically standing up to the machinations of Western imperialism and its regional lackeys, Israel, the Iranian shah, and the "conservative" Arab regimes" (Karsh, 2006, 11).

\section{SOUND HERITAGE}

Nasser's charismatic personality helped him throughout his leadership to be loved and esteemed by Arabs in the Arab world. Nasser established the Voice of the A rabs radio station with waves reaching through all Arab countries which became quite influential and the most popular radio program throughout the Arab region (Alahmad, 2011, p. 2-28). His speeches and songs were greatly received and anxiously awaited by his Arab audience mainly through radio, a medium that was readily available to most of his audience. Radio was the ideal medium for a people [Arabs] whose cultural tradition is oral (Hale, 1975, p. 65). Radio was an important oral communication channel for Arabs (Rugh, 2004). Radio enabled "people to listen to famous Qur"an reciters, musicians, and singers from the comfort of their homes" (Frishkopf, 2010, 68). Diong (2015) showed in a study that the Voice of the Arabs radio station out of Cairo played a significant role in spreading Nasser's pan-Arab ideology across the Middle East. As a result, Nasser became a radio super star more esteemed than prime singers like Um kulthum (Kawkab alSharq, the Star of the East), and abd al-Halim Hafiz (al-Andalib al-Asmar, the Dark nightingale).

Throughout his presidency, Nasser influenced the literary and pop culture. In addition to poetry, and cinema, music production was greatly influenced by his personality and ideology leaving behind a sound culture only unique to him in the contemporary Arab history. He is the only Arab political figure to ever create a political ideology and a rich sound culture that continues to thrive till present. This sound culture not only documents Nasser's era, but also documents Arab's aspirations for unity, freedom and social justice. It became an integral part of the collective memory of Egyptians [and Arabs alike] and one that was passed from one generation to the next (El-Tonsi, 2018). This sound culture is mainly composed of his speeches and the music inspired by his visionary leadership. Nasser's slogans and ideas were present in the 25 January Revolution in Egypt. El-Tonsi (2018) wrote that "many members of Generation $\mathrm{Y}$ have been able to grasp this collective memory while disregarding a great deal of the criticisms made by many of Nasser's detractors." This collective memory is not "a recollection of past events, but rather it constitutes a set of 'pre-established forms' that serve the promotion of a contemporary political goal" (de Bildt, 2016, p. 142). After four decades of his departure, Nasser's sound culture made its passage to social media to connect with all old, current and future Arab generations. Regarding his presence on Facebook, de Bildt (2016, p. 143) noted that "Nasser has become an icon that has the potential of expressing and condensing different ideals associated with him."

\subsection{Speech Culture}

His hours long speeches were broadcasted live over the radio across the Arab world and on television in Egypt. Hundreds of millions of Arabs attentively tuned to his speeches at homes, in cafés, in cars listening to him individually and in groups. His radio addresses became a cultural activity ingrained in the memory of Arab adults and children till present time. His voice is immediately recognized as 'Nasser's voice'.

His speeches were recorded, produced and distributed on tape cassettes in Arab countries by Megaphone Middle East Productions in Cairo (Gordon, 2006, p. 138). They were also dubbed on tapes and sold in Arab cities without caring for 
copyright infringements. All of his speeches are currently available online on Youtube, Facebook, and specialized sites dedicated for his legacy such as Nasser.bibalex.org, Shabaka Nasser alAkhbariya, Nasser.org which hosts a massive collection containing 1,377 audio-visual speeches for Nasser from 1952 to 1970. His speeches continue to be used in the public rallies of Nasserist political movements and radio stations in Arab countries.

A stylistic analysis study found that Nasser has chosen the monologue style to communicate ideas and psychologically influence his audience (Uwaydah, 1971). Since his speeches were exclusively aimed at Egyptian and Arab audience, he employed a style representative of his personality which made remote audience over the radio carefully attentive and involved as if they were in his presence. He used conversational technique, simplicity and repetition in communicating his ideas and thoughts to his audience. This gained him his audience's trust, love and respect. His public addresses and persona are characterized by his personal traits defined by Gordon (2006). As a public star, he was interactive, patriarchal, friendly, warm, credible, honest, convincing, enthusiastic, confident, humble, humorous, and above all an ordinary man from a working-class family like the vast majority of his audience.

His speech, responding to England's use of foul language against him and Egypt, is a good example for Nasser's conversational delivery style and speech characteristics. He used humor in degrading British officials and sounded confident in responding to England's statements reinforcing the end of England's power over Egypt. In another example, Nasser discussed the concept of pride, dignity, honor and freedom in rejecting the United States' economic aid because the Americans as Nasser explained use the aid as a tool to control Egypt and its policies.

In his speech celebrating the British military withdrawal in 1954, Nasser came across as a hero ready to sacrifice himself for the freedom of his people. While Nasser was delivering his speech in Alexandria, broadcast live to the Arab world by radio, he was fired at in an attempt to assassinate him. Rogan (2011, p. 288) wrote:

With great emotion he [Nasser] exclaimed the following:

My countrymen, my blood spills for you and for Egypt. I will live for your sake and die for the sake of your freedom and honor. Let them kill me; it does not concern me so long as I have instilled pride, honor, and freedom in you. If Gamal Abdel Nasser should die, each of you shall be Gamal Abdel Nasser ... Gamal Abdel Nasser is of you and from you and he is willing to sacrifice his life for the nation.
Anyone who listens to Nasser talking realizes that Nasser possessed a pleasant soothing voice with good acoustic qualities, a characteristic that might have played a role in attracting his listeners. "Acoustic analysis of speech is the study of the acoustical characteristics of speech. It involves the physical aspects of spoken language" (Nasser, 8). "Stylistic analysis takes account of the dynamic continuities in communication behaviour. It is concerned with how people talk or sing," (Lomax, 1974 , p. 15). Looking at the paralinguistic qualities of Nasser's speaking style - voice in speech delivery - is vital to this study. "It is at the paracommunicational level, in reaction to small shifts in pitch, loudness, speed, spacing, rhythm, timbre that human beings shape their interaction and assess a situation as friendly, hostile, interesting, and the like" (Lomax, 1974, p. 18). Trager defined as paralanguage -those aspects of vocalization, such as volume, pitch range, vocal timbre (1958, p. 5). "Deduction of human emotions through voice and speech analysis has a practical plausibility and could potentially be beneficial for improving human conversational and persuasion skills" (Dasgupta, 2017 , p. 1). The human voice and associated speech patterns can be characterized by a number of attributes, the primary ones being pitch, loudness or s ound pressure, timbre, and tone (Agus et al, 2010).

In a recent algorithmic study for detection of human emotions, by analyzing various voice attributes and speech patterns, Dasgupta (2017) analyzed human speech in three different situations: Normal emotional state, Angry emotional state and Panicked emotional state. Following the statistical findings of Dasgupta's tests, an analysis of Nasser's paralinguistic qualities showed that Nasser's speaking style belonged to the relaxed and normal emotional state. The following table illustrates the values for pitch, SPL, timbre, and word-timing gaps derived from Nasser's speech samples:

Table 1: Values of vocal statistics obtained from recorded speech samples for Nasser emotional state

\begin{tabular}{|l|l|l|}
\hline \multirow{2}{*}{ Voice Attributes } & \multicolumn{2}{|c|}{ Speech Samples } \\
\cline { 2 - 3 } & Sample 1 & Sample 2 \\
\hline Pitch (Hz) & $8015 \mathrm{~Hz}$ & $8527 \mathrm{~Hz}$ \\
\hline SPL (DB) & -54 & -53 \\
\hline $\begin{array}{l}\text { TIMBRE ASCEND } \\
\text { TIME (S) }\end{array}$ & $0.112 \mathrm{~s}$ & $0.289 \mathrm{~s}$ \\
\hline $\begin{array}{l}\text { TIMBRE DESCEND } \\
\text { TIME (S) }\end{array}$ & $0.297 \mathrm{~s}$ & $0.554 \mathrm{~s}$ \\
\hline $\begin{array}{l}\text { TIME GAPS BETWEEN } \\
\text { WORDS (S) }\end{array}$ & 0.12 & 0.10 \\
\hline
\end{tabular}




\subsection{Political Songs Culture}

An estimated 1,217 national songs were dedicated to him "the most important of which are songs about the Revolution, nationalization of the Suez Canal, the High Dam and the Yemen War" (Nasser.org). Song writers, composers and major singers of his time - Egyptian, Syrian, Lebanese, Algerian and others - chanted for the revolution venerating Nasser's name, character and Arab leadership. Among this group were super stars UmKulthum, Abd al-Halim Hafiz, Mohamad Abd alWahhab, Farid al-Atrash, Soad Mohamad and Fayza Ahmad who were widely loved by Arabs. These singers were well recognized for their dreamy, sentimental romance songs. Um-Kulthum, for example, who was known as the Diva of Arabic song and the Star of the East, mesmerized all Arab generations with her hours long love songs and her unique voice abilities. Additionally, Abd al-Halim Hafiz whose name was closely associated with Nasser was the greatest vocalist for the younger generation. His love songs were by far the most popular among his generation.

Even after the setback in 1967, singers rose to rally a dispirited Arab nation especially the high esteemed star Um Kulthum (Gordon, 2006, p. 121). In memory of the July revolution in 2002, a sound and light show of Abd al-Halim Hafiz's song, Surah [Picture\}, premiered at Liberation Square in Cairo evoking the emotions of the present crowd of the Nasser era, its dreams and hopes. Gordon sees that the sounds played revived the images and power of Nasser's era (2006, p.134).

These songs spoke to the hearts and desires of the Arab audience during and after Nasser's era. "These songs reflected the spirit of the era that has come to be known as the 'age of Nasser' (Gordon, 2006 , p. 2). All of these performers regardless of their status sang for Nasser and their names became affiliated with Nasser's name. These songs were classical Arab songs characterized by their high emotional style in addition to their revolutionary energetic rhythms. At the time, they were channels for propagating Nasser's pan-Arab ideology and social reform. Currently, the messages and values embedded in these songs continue to retain significance in the collective memory and its relationship to the severe conditions of political instability, disunity and social injustice in contemporary Arab countries.

In the song Surah [Picture] by Abd al-Halim Hafiz, broadcasted live in 1966, the song glorifies Nasser, the revolution and all social classes under the banner of the revolution. The song is an ideological celebration of Nasserism.

A picture - we all want a picture,

A picture - under the banner of victory, A picture

of a joyous people under the banner of victory,
Oh, time past, picture us - we will draw close to each other again,

And anyone who keeps his distance from the field of vision will never appear in this picture. All of us in the picture are colleagues, fulfilling what the Character called for,

From the youngest child in braids, on the farms and in schools, moving in sync,

To the peasant, the essence of good and beauty, To the preacher, Guardian of the Qur'an,

To the soldier, the lion, who ears on his shoulders the armor of the nation ... Professors, scientists, factory workers and doctors from the working folk,

Men behind their desks serve you with good spirit

This picture has no slackers sleeping on the job! It has nothing but total revolutionary Egyptian Arab individual ...

Al-Wattan al-Akbar [The Greater Homeland], 1960, was the first Arab operetta composed by Mohamad abd al-Wahhab and sung by a group of famous singers: Abd al-Halim Hafiz (Egypt), Sabah (Lebanon), Shadya (Egypt), Fayza Ahmad (Palestine), Warda (Algeria), and Najat al-Saghira (Egypt). This operetta talked about Gamal's revolution, triumphs, Arab unity, and the fight against colonial occupation. It amalgamated Nasser's name with the revolution using the meaning of his first name Gamal [beauty] next to revolution; Gamal al-Thawra [the beauty of the revolution]

Chorus:

My dear homeland

The greatest of homelands

Day after day

Its glories multiply

And its life is rife with victories

My homeland grows and becomes free

My homeland.. My homeland

Singer Abd al-Halim Hafez:

Oh my homeland, your love rules my heart My homeland, the homeland of all Arabic people You are the one who called for the ultimate unity After seeing the beauty of the revolution

You are great

And much greater

Than all existence

Than all eternity

Oh, my homeland ...

\section{COMCLUSION}

In retrospect, Nasser successfully created an Egyptian, pan-Arab sound culture only unique to him throughout contemporary Arab history. The acoustic strategies involved in the production of this 
culture are a rich contribution to radio form and history.

Nasser's speeches and the songs made about him represented Nasser's ideology and transmitted its values throughout the Arab world in an emotionally affective style. It offers an insight on how such geographically spread, large scale listening communities were influenced by themes of unity and social reform through a distinct timbre voice.

Gamal's sound culture left its imprint on the Arab thought and became embedded in Arab consciousness. No other leader in the region had cultivated such effect. Other influential Arab leaders attempted to emulate Nasser's media experience through speech performance and musical productions, such as Saddat of Egypt, Saddam of Iraq, and Qaddafi of Libya.

Nasser's heritage remains alive and those songs and speeches still echo among people on occasions and other political rallies. It continues to affect audiences regardless of political alignments reinforcing Nasser as a sound Super Star and a pan-Arab icon, which is worthy of further survey research on how he is perceived fifty years after his departure.

\section{REFERENCES}

Agus T. et al, (2010) 'Characteristics of human voice processing'. IEEE International Symposium on Circuits and Systems (ISCAS), Paris, France. May 2010. 509-512.

Ajami, F. (1979) 'The end of pan-Arabism'. Foreign Affairs, 57(2). 355-373.

Alahmed, A. (2011) 'Voice of the Arabs radio: Its effects and political power during the Nasser era (1953-1967)'. The J oint Journalism H istorians Conference. Available at: http://ssrn.com/abstract=2047212 (Accessed: May 31 2019).

Dasgupta, P. B. (2017). 'Detection and analysis of human emotions through voice and speech pattern processing'. International $J$ ournal of Computer Trends and Technology (IJCTT), 52(1). 1-3.

Dawisha, A. (2009) Arab $n$ ationalism i $n t$ he twentieth century: From triumph to despair. Princeton University Press: Princeton.

De Bildt, J. (2016) 'The use of facebook for examining collective memory', In Lucy Bond, Stef Craps, Pieter Vermeulen (eds), Memory unbound: Tracing the dynamics of memory studies. Berghahn Books: NY. 133-148

Diong, N. J. N. (2015) 'Sawt a l-Arab or sawt alNasser? The case of mass media under Gamal Abdel Nasser and the convoluted rise of pan-
Arabism'. Journal of $G$ eorgetown $U$ niversity Qatar Middle Eastern Studies Student Association, 2015:5. Available at: http://dx.doi.org/10.5339/ messa.2015.5 (Accessed 7 July 2019).

El-Tonsi, A. (2018) 'The legacy of Nasserism'. Ahramonline Monday 15 Jan 2018. Available at: http://english.ahram.org.eg/News/288198. aspx (Accessed: 5 August 2019).

Frishkopf, M. A. (2010) Music and media in the Arab world. The American University in Cairo Press: Cairo.

Gordon, J. (2006) Nasser: hero of the Arab nation. Oneworld Publications: Oxford.

Hale, J. (1975) Radio $p$ ower: Propaganda a nd international br oadcasting. Temple University Press: Philadelphia.

Hanna, S. A. and Gardner, G. H. (1969) Arab socialism, [ al-Ishtirakīyah al -'Arabīyah]: A documentary s urvey. University of Utah Press: Salt Lake City.

Hourani, A. (1991) A history of the A rab p eoples. Faber \& Faber: London.

Jankowski, J. P. (2001) Nasser's E gypt, Arab nationalism, and the United Arab Republic. Lynne Rienner Publishers: Boulder, CO.

Karsh, E. (2006) 'Arab imperialism: The tragedy of the Middle East'. Mideast Security and Policy Studies. 69. 1-34.

Kerr, M. (1971) The Arab c old w ar: G amal 'Abd alNasir and his rivals, 1958-1970. Oxford University Press: Oxford.

Lomax, L. (1974). 'A stylistic analysis of speaking'. Language in Society, 6. 15-36.

Rogan, E. (2011) The A rabs: A hi story. Basic Books: NY.

Rugh, W. A. (2004) Arab Mass Media: Newspapers, Radio, and Television in Arab Politics. Praeger: Westport, CT.

Searle, C. (2001) 'And his name is Nasser: cricket and the Suez crisis'. Race \& Class, 43(1). 5969.

Trager, G. L. (1958). 'Paralanguage: A first approximation'. Studies in Linguistics, 13. 1-12.

Uwaydah, M. (1971) 'An examination of some structural and rhetorical features in certain speeches of Gamal Abdel Nasser'. MA thesis, American University of Beirut. 